\title{
Sectoral analysis of foreign direct investment and growth in Nigeria
}

\author{
Orogwu C. David ${ }^{1, *}{ }^{\dagger}$, Fakayode, B. Segun ${ }^{2, \dagger}$, Mohammed H. Itopa $^{1, \dagger}$ and \\ Ahmed Abdulbasit ${ }^{1}{ }^{\dagger}$
}

${ }^{1}$ Division of Agricultural Colleges, Ahmadu Bello University, Zaria and ${ }^{2}$ Federal University of OYE-EKITI, Ekiti

* corresponding author: orogwudavid@gmail.com

${ }^{\dagger}$ Auhtors Contributed equally.

\begin{abstract}
Background: The study conducted a sectoral analysis of the contribution of foreign direct investment on Nigeria economy between 1980-2019. Methodology: Time series data from Central Bank of Nigeria and World Bank Development Indicators was used to estimate the relationship using Auto Distributed Lag Model (ARDL). Findings: It was revealed that foreign direct investment not only exert a direct positive effect on the aggregate growth rate of Nigeria economy but also exert a positive indirect effect through labour. It was also discovered that agriculture sector is the only sector that does not enjoy significant contribution of foreign direct investment in Nigeria while petroleum and Gas experience the greatest growth attributable to foreign direct investment in Nigeria. The study contributed to literature by not only examining the indirect effect of foreign direct investment on Nigeria aggregate growth rate through labour but also the effect of foreign direct investment on the sector-by-sector growth rate.
\end{abstract}

Key words: Foreign direct investment; FDI; Economic Growth; Sectoral analysis of FDI; Nigeria; ARDL.

\section{Introduction}

Classical and neo-classical economics theory projected convergence between poor developing countries and the developed countries in the long-run largely due to transfer of technology and capital from the developed countries to the developing countries. One of the way capital and technology are transferred from developed countries to developing countries is through the inflow of foreign direct investment (Romer; 2012).

It is predicated on the assumption that capital tends to move from saturated developed market where cost of capital is low to the underdeveloped market with high cost of capital mostly in the developing countries. This was first discovered by Mundell (1957) when the author argued that trade improves capital formation where capital flow from countries with low returns on capital to countries with high returns on capital.
But early researchers like Dunning (1979) noted that the reason for the flow of capital or direct investment from the developed countries to the developing countries is influenced by not only the returns on capital but also the needs for the MNCs Corporation to protect their investment in those developing countries. Ikpesu (2019) opined that MNCs products competes with local industries in foreign market with several tariff as a result the MNCs often decides to establish subsidiary in the local market to beat the tariff and get their goods to the target market easily thereby competing favourably with the local markets. The work of Dunning (1979) noted that MNCs engages in direct investment basically for three core advantages they possess which include ownership advantage, location advantage, and internationalisation advantages.

As argued by Jaiblai and Shenai (2019) the MNCs can only engage in direct investment when they believe they either or 
all the three advantages are available at their disposal. The ownership advantages focused on whether the MNCs have the managerial capability advantage, better and improved technological efficiency, and resource abundance. On the other hand, the location advantages argued that the MNCs invest where they believe that the foreign market have some relative economic stability, abundant natural resources, and other opportunities to be exploited. The managerial capabilities and technological advancement possessed by the MNCs are expected to spill to the host countries domestic firms and employees migrate from the MNCs to the local industries. Obida and Abu (2010) noted that FDI does not only improves capital formation in developing countries like Nigeria but also improves employment generation through its positive technological and managerial spillover effect on the local industries.

As opined by Jaiblai and Shenai (2019) that the MNCs positive spillover to the local industries occurs in four basic channels which include imitation, worker mobility (arguably the most important channels), competition, and linkages. The point is that the domestic firms have the chance of imitating the technological capabilities, managerial styles, products development through constant observation of the MNCs operation over time. Although, maintained that the extent of domestic firm imitating the MNCs depends technological gap between the domestic firm and the MNCs (Gachino; 2007). Similarly, positive spillover can also occurs through workers mobility, where employees from the MNCs migrate to the domestic firms thereby sharing the work experience and managerial capabilities gain with the domestic firms. Positive spillover often occurs also through intense competition from the MNCs thereby forcing the domestic firms to adopt technological capabilities and improved operation thereby increasing the domestic firms output.

Increase in the domestic firms output equally increases the economic growth of the host country (Faroh and Hongliang; 2015; Adeleke and Olowe; 2014; Joseph et al.; 2021). It is simple, as the domestic firm keep imitating the MNCs strategies, and the employees keep migrating from MNCs to work in the domestic firms or establish a competing firm, the domestic firm output will expand, and the output of the economy will expand explaining the positive relationship that exist between foreign direct investment and economic growth over time. However, there is a downside of FDI on economic growth of the host country particularly when the fact that intense competition from the MNCs can force the domestic market out of the market require careful analysis of the discussion of the impact of FDI on economic growth (Adeleke and Olowe; 2014).

Globally, the impact of foreign direct investment on economic growth have largely be acknowledged by economic literature this is reflected by several strategies adopted by both developed and developing countries to attract more foreign direct inflow. Jones and Yama (2016) noted that most developing countries like Nigeria who earlier adopted restrictive policies are now adopting policies that encourages the inflow of foreign direct investment. In fact, Nigeria government has established several bodies aimed at promoting FDI in the country such as 'Nigerian Investment Promotion Commission (NIPC) Act' which was established to promote, encourage, and attract foreign direct investment into the country thereby increasing the country FDI inflow since its establishment in 1995.

The inflow of FDI across countries have over time skyrocketed as much as \$2.56 trillion in 2017 from \$0.498 billion in 1970. In African, the total inflow of FDI to the continent in
2017 is US\$ 42 billion which is about only 6 percent of total FDI inflow (US\$ 42 billion) to the developing countries. As African received just 6 percent of the FDI inflow to developing countries, continents like Asia received a whole sum of 71 percent while Latin America and the Caribbean received 23 percent. Interestingly, of the US\$ 42 billion FDI received in Africa in 2017, Egypt received the highest ( $\$ 7.4$ billion), followed by Ethiopia ( $\$ 3.6$ billion), Nigeria comes in the third place despite their resource abundance and huge market size (\$3.5 billion). Morocco was the fifth country for that year receiving about $\$ 2.7$ billion (UNCTAD; 2018).

Evidence revealed that Africa in general and Nigeria have been performing poorly in terms of FDI inflow largely because most of the African countries adopted policies that hinder foreign investment in the past or fail to deal with structural deficiency that impedes effective operation of MNCs in the local market. Such deficiency includes infrastructural decay, poor or no respect for the rule of law, harsh business environment, political violence, political instability, among others (Ikpesu; 2019). It is argued that developed countries received close to 70 percent of the world FDI and is dominated by the US, China and Europe. The implication is that Nigeria is not the highest recipient of FDI in Africa despite the availability of abundant natural resources and large market.

Several literature have investigated the impact of foreign direct investment on economic growth either from a national level (Ikpesu; 2019; Jaiblai and Shenai; 2019) or from global or regional level (Adeleke and Olowe; 2014) yet the impact of FDI still remains controversial. Similarly, what determine the inflow of FDI in a country is still evolving a nations of the world keep adopting new strategies to increase its inflow in their economy. While most literature founds that there exist positive impact of FDI on economic growth (Jaiblai and Shenai; 2019; Faroh and Hongliang; 2015), studies like Adeleke and Olowe (2014) noted that there exist negative spillover effect of FDI on the host countries through crowding out the domestic firms. Studies like Akinlo (2004); Anochiwa et al. (2018) found no strong evidence to conclude whether there is positive or negative spillover effect on the domestic firm that can propel economic growth. What is yet to be explored is whether the inflow of FDI in Nigeria promoted economic development as the country developmental indicators keep on deteriorating. Recently, Nigeria took over from India as the country with the most extreme poverty cases, youth unemployment is about 66.5 percent, low-capacity utilization and other major economic and social issues. Thus, this study conduct sectoral analysis of the impact of foreign direct investment on Nigeria economy.

\section{Literature Review}

Foreign direct investment in itself has been defined by different institutions and body. For instance, the OCED benchmark definition of FDI (4th edition) and UNCTAD sees FDI as a kind of foreign investment where an entity of a resident country (parent company or Multinational corporation) acquired a long-lasting interest in an entity resident in another country (subsidiary company) other than the country of the entity where the parent company have at least 10 percent voting power in the entity. The implication is that for a foreign investment to be regarded as FDI the parent company must own at least 10 percent of the capital of the organisation and the direct investor must be individual or entity whose resident is different from the country of investment (Banco; 2003).

It is important to note that not all kind of foreign invest- 


\begin{tabular}{|l|l|}
\hline Theory & $\begin{array}{l}\text { Factors attracting FDI into Host } \\
\text { countries }\end{array}$ \\
\hline $\begin{array}{l}\text { Differential rate-of-returns } \\
\text { theory }\end{array}$ & $\begin{array}{l}\text { Labour -costs } \\
\text { Exchange rate } \\
\text { Interest rate } \\
\text { Tax policy and subsidy policy } \\
\text { Returns on capital } \\
\text { Economic size } \\
\text { Competition }\end{array}$ \\
\hline Portfolio Diversification Theory & $\begin{array}{l}\text { Economics risk factor } \\
\text { Political risk factors } \\
\text { Cultural risk factors } \\
\text { Other risk }\end{array}$ \\
\hline Kojima Hypothesis & $\begin{array}{l}\text { Raw materials availability in the country } \\
\text { Cost of labour } \\
\text { Interest rates } \\
\text { Exchange rates }\end{array}$ \\
\hline Eclectic (OLI) theory & $\begin{array}{l}\text { Raw material availability } \\
\text { Availability of technology in host country } \\
\text { and MNCs. } \\
\text { Host country incentives to FDI } \\
\text { Infrastructural development } \\
\text { Trade policy of the host country. }\end{array}$ \\
\hline
\end{tabular}

Source: Author (see also Dunning, 2001).

Figure 1. Determinant of FDI inflows to host countries theoretical explanation

ment is categorised as foreign direct investment. As captured in the definition any foreign investment where the direct investor (MNCs) does not have at least 10 percent stake in the investment cannot be categorised as FDI but can be either categorised as portfolio investment or any other class of investment. Researchers often confuse portfolio investment to foreign direct investment. Foreign direct investment can also be classified into Greenfield and Brownfield investment. The greenfield investment is where the parent company of the MNCs establish new branch from scratch in the host country while brownfield is where the MNCs partners with another domestic firm in the form of merger and acquisition, joint venture, and others (UNCTAD; 2018).

\subsection{Theoretical Exposition}

The determinant of FDI and its impact on the host countries have been evolving and lots of literature have examined the relationship between FDI and economic growth across countries. FDI determinant can be traced back to the work of Smith (1776) when the classical economist hinted on the reason why nations of the world engage in international trade. It was discovered in Smith absolute cost advantage theory that two economies can engage in international trade if the one economy (say country 1) can utilise labour and capital more efficiently in producing a product say product $\mathrm{A}$ at a least cost compared to country 2 .

However, FDI origin started formerly with the work of Mundell (1957) when he argued that capital move from countries with low return on investment (capital) to countries with high interest rate or returns on capital. Hymer (1976) in his theory of FDI noted that MNCs does not only engage in FDI because of high interest rate but also because of the imperfect market structure experienced in developing economy which they intends to take advantage given their resource abundance, technology capabilities, information advantage, and managerial capabilities. Banco (2003) noted that when MNCs are unable to fully take advantage of the imperfect market in developing countries there occurs positive spillover effect to the firms in the economy which is a source of economic growth (Denisia; 2010).

It was the eclectic theory of FDI based on the work of Dunning (1979) that gave a better and comprehensive explanation of the determinant of FDI across countries. Eclectic theory explain FDI from three perspective: ownership, location, and international advantage. According to Denisia (2010) FDI flow to a country when the MNCs considers the availability of resources or asset capable of giving the organisation advantage over other competing firms in the local economies. Such assets or resources include tangible and intangible assets owned by the MNCs that can easily be transferred to the place of direct investment with little costs. Thus, Nayyar (2014) noted that in such situation, FDI will only occur when the MNCs perceives the advantages to outweigh the disadvantages of implementing the policy of FDI.

On the other hand, the location advantages of the FDI seems to complement the ownership advantages in that the MNCs considers countries that have more economic opportunities like natural resources, stable exchange rate, low inflation rate, large market size etc., less political and cultural risk factors like political instability, government policies instability, weak institution, poor rule of laws, lack of cultural diversity, poor attitude towards strangers etc. (Denisia; 2010; Nayyar; 2014). The last perspective of the eclectic theory is the international advantages. Here the MNCs consider policies regarding FDI in a country, nearness of the location to the consumer market 
among others. The MNCs will be interested to know whether the country respect intellectual property rights, franchise policies and many others (Adamu et al.; 2015; Acaravci and Ozturk; 2012).

There are certain factors that have been identified are the leading determinant of FDI inflow into host countries by different theories, few of these factors are identified below in Figure 1 following the work of (Dunning; 1979).

It is important to note that the above determinant of FDI across nation further depends on the strategies driving the MNCs towards investing in other countries outside the direct investor country. For instance, a MNCs strategies can range from market seeking -strategy, efficiency seeking -strategy, natural resource seeking -strategy, and asset seeking -strategy. The market seeking MNCs can be further grouped into defensive market seeking investors whose target is to prevent host country tariff and other barriers while the effective market seeking MNCs aimed at taking advantage of the growing developing or developed market (Nayyar; 2014).

According to Osuji (2015b) the efficiency MNCs seeking strategy aimed at ataking advantage of host countries (especially developing countries) low cost of production especially labour. Here the MNCs produce cheap at the host country and ship back to the home or nearby market.

The market-seeking investors servicing the host country and its close neighbour. It can further be grouped into defensive market-seeking investors that aim at preventing host country tariff and non-tariff barriers and the offensive marketseeking investors that aimed at taking advantage of the growing market. Similarly, efficiency- seeking investors aimed at taking advantage of low production cost in the host country and ship the produced goods to either the home country or other markets (Dunning; 1979; Osuji; 2015b). Most FDI in the Asian countries are often efficiency seeking investors. Similarly, the natural resources seeking strategies of the MNCs aimed at seeking natural resources in country where it is available and export back to home country. Arguably, most of the FDI into Nigeria are either natural resource seeking strategies of efficiency seeking strategy. This can be better explained in Figure 2 below.

Ikpesu (2019) share the view that the poor inflow of FDI into Nigeria can be attributed not just to economic reasons like macroeconomic instability, but rather to political and social violence prevalent in the country. Given the fact that majority of the FDI following into Nigeria are natural resources seeking MNCs, the political and social violence prevalent in the Northern part of the country (Bokoharam activities) and in the south the activities of the Niger-Delta militants who are bent on destroying some of the MNCs facilities.

\subsection{Nigeria Strategy in Attracting FDI}

Nigeria, like every other nation either developed and developing countries are developing strategies to attract more foreign direct investment. There are basically 10 categories of policies developed by nations of the world in attracting FDI, which include: investment and investment promotion policy, human capital development policy, trade policy, ethical best business practice policy, competition policy, infrastructure development policy, taxation policy, financial sector policy, and corporate governance (UNCTAD; 2018). The policy development of most countries are often directed towards meeting the demands or policy expectation of the MNCs: For instance, UNCTAD (2018) noted that MNCs look at the following factors when considering where to invest.

\begin{abstract}
"foreign exchange regulations, taxation, employment, including employment of non-citizens, land issues, competition policy, rule of law and respect for property rights, intellectual property protection, corporate governance and accounting standards, licensing and administration of regulations and investment promotion including incentives, macroeconomic framework" (UNCTAD; 2018).
\end{abstract}

Nigeria since independence have adopted series of policies that either aimed at promoting foreign trade of restricting foreign trade in the country (Anochiwa et al.; 2018; Anowor et al.; 2013). For instance, prior to independence Nigeria under the leadership of the Great Britain enacted series of policies aimed at promoting foreign investment inflows from Britain and other none Britain countries such as 'Nigeria industrial tax relief act of 1958'. The policy aimed at subsidising tax rate for British firms investing in Nigeria.

However, at independence, Nigeria origin took power from the Great Britain for self-governance and there arise the need for full control of resources. It was believed then that the Britain are the ones controlling the economic life of Nigeria As such, some key individuals within the government agitated for such structural deficiency in government policy. It was at that point that point that Nigeria government introduces series of policies aimed at reducing foreign investors stake in firms operating in Nigeria. This prompt the introduction of 'exchange rate control act of 1962'. The policy restricts the move or transfer of fund outside the sour of Nigeria to other countries without express approval from the federal government. Ikpesu (2019)) noted that this serve as the first restrictive policy adopted by the government.

The above policy was perceived by many especially the military personnel in authority as not very effective in restricting the activities of the foreigners in the operation of Nigeria economy. This prompted the introduction of indigenisation policy in 1972. The policy provides minimum stakeholder share a foreign firm must possess to operate in Nigeria on about 22 class of firms within Nigeria including but not limited to manufacturing firms, processing firms, transportation firms, and many others (Jones and Yama; 2016). The policy was seen not very effective and let to the introduction of 'Nigerian Enterprises Promotion Decree (NEPD), No. 4 of 1972' and the second one in 1977, this reduces direct investor stake from previous 60 percent to 40 percent stake prompting most of the MNCs operating in Nigeria as at that time to partner with local investors in sustaining their firms among others.

However, with decline in oil revenue in the early 1980 s and subsequent rise in literature advocating for inflows of foreign investment as a driver of economic growth, Nigeria, and other developing countries especially Africa started relaxing foreign trade restriction policies like that of indigenisation policy. This prompted Nigeria to relax the indenisation policy in 1989 to only single line of business activities. The continuous decline in foreign investment in Nigeria and emergence of literature on the miracle of the Asian tigers that adopted more liberal policies which encouraged inflow of foreign direct investment further prompt the federal government to introduce such policy as 'Nigerian Investment Promotion Decree' (Tonuchi and Onyebuchi; 2019).

The decree provides the body with the mandate of attracting foreign investment in the country by promoting the image of the country in the heart of MNCs through establishing a good working relation and business environment with the MNCs. 


\begin{tabular}{|c|c|c|c|}
\hline Strategy & $\begin{array}{l}\text { Economic } \\
\text { determinants }\end{array}$ & Political determinants & Other determinants \\
\hline $\begin{array}{l}\text { Market } \\
\text { seeking -FDI }\end{array}$ & $\begin{array}{l}\text { Nominal GDP } \\
\text { GDP growth rate } \\
\text { GDP per capita } \\
\text { Past FDI } \\
\text { Real wage } \\
\text { Cost of transportation } \\
\text { Import restrictions }\end{array}$ & $\begin{array}{l}\text { Performance requirement } \\
\text { Price control } \\
\text { Convertibility of foreign. } \\
\text { Sector-specific controls } \\
\text { Market access -constraints } \\
\text { Exchange rate policy }\end{array}$ & $\begin{array}{l}\text { Cultural differences } \\
\text { Language barriers } \\
\text { Population } \\
\text { Geographical location }\end{array}$ \\
\hline $\begin{array}{l}\text { Efficiency } \\
\text { Seeking FDI }\end{array}$ & $\begin{array}{l}\text { Inflation rate } \\
\text { Exchange rate } \\
\text { Wage rate } \\
\text { Interest rates } \\
\text { Infrastructure } \\
\text { development } \\
\text { Savings rates }\end{array}$ & $\begin{array}{l}\text { Tax/subsidies } \\
\text { Ownership constraints } \\
\text { Trade agreement } \\
\text { FDI incentive/restrictions } \\
\text { Price control } \\
\text { Trade agreement }\end{array}$ & $\begin{array}{l}\text { Existence of -suppliers } \\
\text { Labour availability } \\
\text { Geographical location } \\
\text { Culture }\end{array}$ \\
\hline $\begin{array}{l}\text { Natural } \\
\text { resources - } \\
\text { seeking FDI }\end{array}$ & $\begin{array}{l}\text { Raw materials price } \\
\text { Transport cost } \\
\text { Infrastructure } \\
\text { Domestic investment }\end{array}$ & $\begin{array}{l}\text { FDI incentives } \\
\text { FDI restriction } \\
\text { Interested sector-specific } \\
\text { policies }\end{array}$ & $\begin{array}{l}\text { Existence of raw } \\
\text { materials } \\
\text { Culture and attitude of } \\
\text { the host country }\end{array}$ \\
\hline $\begin{array}{l}\text { Strategic- } \\
\text { asset seeking } \\
\text { FDI }\end{array}$ & $\begin{array}{l}\text { Infrastructure } \\
\text { Investment in } \mathrm{R} \text { and } \mathrm{D} \\
\text { Inflation rate }\end{array}$ & $\begin{array}{l}\text { Property protection } \\
\text { FDI incentive and restrictions } \\
\text { policy } \\
\text { Risk factors } \\
\text { Innovation -policy }\end{array}$ & $\begin{array}{l}\text { Trademark } \\
\text { Patent right }\end{array}$ \\
\hline
\end{tabular}

Source: Author

Figure 2. Determinant of FDI inflow to host countries based on MNCs Strategies

The institution was also mandated to build a working relation with international trade organisations like UNIDO, 'Multilateral Investment Guarantee Agency' (MIGA), and others. Unlike the indigenisation policy, the 'Nigerian Investment Promotion Decree' provides the multinational to own investment up to 100 percent in Nigeria (Tonuchi and Onyebuchi; 2019; Adeleke and Olowe; 2014).

Other policies that was established to promote FDI in Nigeria include policy like 'Foreign Exchange Monitoring and Miscellaneous Provisions (FEMAMP) Act'. The policy liberalised Nigeria foreign exchange. Interestingly, Nigeria became member of World Trade Organisation (WTO) in 1995, though the agreements which relates to aspect of intellectual property right was rectified in January 20th 2017 aimed at promoting world trade across country (Tonuchi and Onyebuchi; 2019).

Nigeria is part of the Sub-Saharan African country which are granted tariff free policy on goods entry US under the African Growth and Opportunity Act (AGOA), in 2017, the country equally signed a joint a 'Joint Declaration on cooperation' with European free trade area. The government has also entered into other various trade and bilateral agreement with other countries. Prominent among that bilateral trade agreement is the Nigeria currency swap with China of \$2.5billion.

\subsection{Foreign Direct Investment and Nigeria Economic Growth}

Several empirical works have investigated the impact of FDI in the host economy in terms of propelling economic growth and development through either positive or negative spillover effect on the host economies (Ikpesu; 2019; Jaiblai and Shenai; 2019; Anochiwa et al.; 2018; Faroh and Hongliang; 2015; Akinlo;
2004). Spillover effects can either be backward spillover or forward spillover effects. A backward spillover effect occurs when the domestic firms directly benefit from the MNCs because of providing services or goods to the MNCs in the country. In Nigeria this happen in the upstream sector (Anochiwa et al.; 2018; Jones and Yama; 2016; Osuji; 2015a; Okoli and Agu; 2015). Similarly, forward spillover effects happens when the domestic firms generate positive spillover effects to MNCs in downstream sector. Most of the empirical studies reviewed found positive spillover or positive impact of FDI on economic growth while few studies who found negative effect (Gachino; 2007) while study like Akinlo (2004) could not conclude whether there is positive or negative relationship.

\section{Methodology}

\subsection{Data Source}

The data is sourced from World Bank Development Indicators (WDI). The data used for the analysis span from the year 1980 to 2019. The sectoral share contribution or value added from each of the sector is used for the analysis. The employment data is also share of employment from each of the sectors as contained in WDI data bank. The study relied also on data from Central Bank of Nigeria for the share of contribution of each of the sectors on the overall growth. 


\subsection{Model Specification}

We use a modified Cobb-Douglas production function in its log form:

$$
g y_{t}=\ln A+\alpha \ln L_{t}+\beta \ln K_{t}+\gamma \ln F_{t}+\sum_{n=1}^{\infty} \theta_{s} \ln Z_{t-s}+\mu_{t}
$$

Where; $g y$ is the growth rate of sector value added (henceforth called growth rate of value added), $\mathrm{L}, \mathrm{K}$, and $\mathrm{F}$ are labour, domestic capital, and foreign capital - in this case stocks of foreign inward FDI respectively. Also, $\mathrm{Z}$ is the vector of control variables in the level form and $\mu_{t}$ is the stochastic error term. We assume further than all the series coefficients are individually less than unity but could be collectively above unity since we do not assume constant return to scale.

Since, several papers have robust FDI impact on growth through its interaction with labour, and fewer article finding much effect on domestic capital or total factor productivity. We rewrite the labour coefficient as in equation (2);

$$
\alpha=\alpha_{1}+\alpha_{2} \ln F_{t}
$$

Substituting Equation (2) into equation (1) yields.

$$
g y_{t}=\ln A+\alpha_{1} \ln L_{t}+\alpha_{2} \ln L_{t} \ln F_{t}+\beta \ln K_{t}+\gamma \ln F_{t}+\sum_{n=1}^{\infty} \theta_{s} \ln Z_{t-s}+\mu_{t}
$$

Equation (3) can be rewritten in its empirical to get the model for the aggregate effect of FDI as in equation (4):

$g y_{t}=\beta_{0}+\beta_{1} \ln L_{t}+\beta_{2} \operatorname{lnFDI} I_{t}+\beta_{3} L_{A B F D I_{t}}+\beta_{4} \ln D K_{t}+\sum_{n=1}^{\infty} \beta_{s} \ln Z_{t-s}+\mu_{t}$

Where; $g y$, is the growth rate of the value added, $\ln L$ is the $\log$ of labour, LABFDI is the log of labour and FDI interaction, DK is the log of domestic capital, FDI is the log of foreign capital (FDI), $\mathrm{Z}$ is the log of other control variables. The equation for sectoral impact of FDI is given as in equation (5):

$$
\begin{array}{r}
S g y_{t}=\beta_{0}+\beta_{1} \ln L_{t}+\beta_{2} \ln F D I_{t}+\beta_{3} L A B F D I_{t}+\beta_{4} \ln D K_{t}+ \\
\sum_{j=1}^{5} \delta_{j} S_{j} F D I_{t}+\sum_{j=1}^{5} \Phi_{j} S_{j} L A B F D I_{t}+\sum_{j=0}^{\infty} \beta_{j} \ln Z_{t}+\mu_{t}
\end{array}
$$

Where; $S g y_{t}$ is growth rate of sector value added, $S_{j}$ is the sectoral dummies, $j=1,2, \ldots \ldots \ldots, 5$ that is, $\beta_{2}$ reveals the effect of FDI on the base sector and $\beta_{2}+\delta_{j}$ on each of the other 5 sectors. Similarly, $\beta_{3}$ is a measure of the effect of LABFDI on the base sector and $\beta_{2}+\phi_{j}$ on each of the 5 sectors. To analyse the relationship Autoregressive Distributed Lag model (ARDL) will be employed. For one independent variable, the general form of ARDL estimation approach is given in equation (6) below.

$$
g y_{t}=\alpha+\beta(L) x_{t}+\mu_{t}=\alpha+\sum_{s=0}^{\infty} \beta_{s} x_{t-s}+\mu_{t}
$$

Equation (5) can be transformed in its ARDL form to read as;

$$
\begin{array}{r}
S g y_{t}=\beta_{0}+\sum_{i=1}^{n} \beta_{1} \Delta S g t_{t-i}+\sum_{i=0}^{n} \beta_{2} \Delta \operatorname{lnL} L_{t-i}+\sum_{i=0}^{n} \beta_{3} \Delta F D I_{t-i} \\
+\sum_{i=0}^{n} \beta_{4} \Delta L A B F D I_{t-i}+\sum_{i=0}^{n} \beta_{5} \Delta D K_{t-i}+\sum_{i=0}^{n} \beta_{6} \Delta \theta_{j} S_{j} F D I_{t-i} \\
+\sum_{i=0}^{n} \beta_{7} \Delta \Phi_{j} S_{j} L A B F D I_{t}+\mu_{t}
\end{array}
$$

Where $\ln$ is the natural $\log , \Delta$ represents difference operator, and $\alpha_{t}$ represents drift component. The summation signs $\left(\beta_{1}-\beta_{7}\right)$ captures short-run dynamic of the model, similarly, $\left(\phi_{1}-\phi_{7}\right)$ captures the long-run relationship, and $\mu_{t}$ represents the uncorrelated disturbance term. The Bond testing null and alternative hypothesis is captured below.

To determine the short run at the ECM framework, the study computes an F-statistics. The test also computes two asymptotic critical values, lower and upper bond value. Where the lower-bond -assume that the variables are integrated of order zero while the upper bond-value assume that all the variables are integrated at first order. The key merit of ARDL is in its flexible nature especially with small sample size and great when variables are of different order of integration. The data will be first subjected to unit root test to ascertain whether the data is free from stationarity.

\section{Result and Discussion}

The unit root test revealed that the series are of different order of integration. The unit root test revealed that only the growth rate of the share of the sector (value added) and domestic capital is not stationary at level while the rest of the series are stationary at level. However, other series became stationary at first difference as seen in Table 1.

\subsection{ARDL Bounds Tests for Co-integration}

To empirically analyse the long-run relationships and short run dynamic interactions Sectoral Foreign Direct Investment (E) and the Nigeria economy, the researcher applies the autoregressive distributed lag (ARDL) co-integration technique. The techniques is assumed to perform better than other estimation techniques for small sample size like ours and lastly it used by many authors to solve endogeneity issues since the lag of the dependent variable is included among the regressors.

In ARDL estimation techniques the next step after validating the order of integration is to determine the validity of the model by subjecting the model to serial correlation test using Breusch-Godfrey test and stability test using sum of recursive residuals (CUSUM) (Pesaran and Shin; 1999; Peters et al.; 2020). Breusch-Godfrey Serial Correlation as in table 2 revealed that the Observed $\mathrm{R}$-squared is 6.986 with a $\mathrm{P}$-value of 0.1225 . Since the $P$-value is greater than the chosen level of significance [0.05], the null hypothesis cannot be rejected. The implication is that the model does not have serial correlation. The model is tested also for stability using CUSUM test as in Figure 3

The F-statistic value is 7.64724. The first level is calculated on the basis that GDP included in the ARDL model is integrated of order zero, while the second, third and fourth variables are calculated on the basis that the variables are integrated of order one. The result revealed that there exist longrun relationship between economic growth and foreign direct investment since its F-statistic (7.6474) is higher than the upper-bound critical 


\begin{tabular}{llllll}
\hline Variables & Level Statistics & 1st Diff. Sta. & Critical Value & Order & Remark \\
\hline gy & -2.0211 & -5.41056 & -3.57424 & $1(1)$ & Stationary \\
Labour & -3.7189 & - & -3.57424 & $1(0)$ & Stationary \\
FDI & -4.6737 & - & -3.57424 & $1(0)$ & Stationary \\
LABFDI & -6.25392 & - & -3.57424 & $1(0)$ Stationary & \\
Domestic capital & -0.5570 & -3.59336 & -3.57424 & $1(1)$ & Stationary \\
\hline
\end{tabular}

Table 1. ADF Unit Root Result Test at Level and First Difference

$$
\begin{array}{llll}
\text { F-statistic } & 5.355 & \text { Prob. } & \mathrm{F}(2,10) \\
\text { Obs*R-squared } & 6.986 & \text { Prob. Chi-Square(2) } & 0.1225
\end{array}
$$

Table 2. Breusch-Godfrey Serial Correlation LM Test

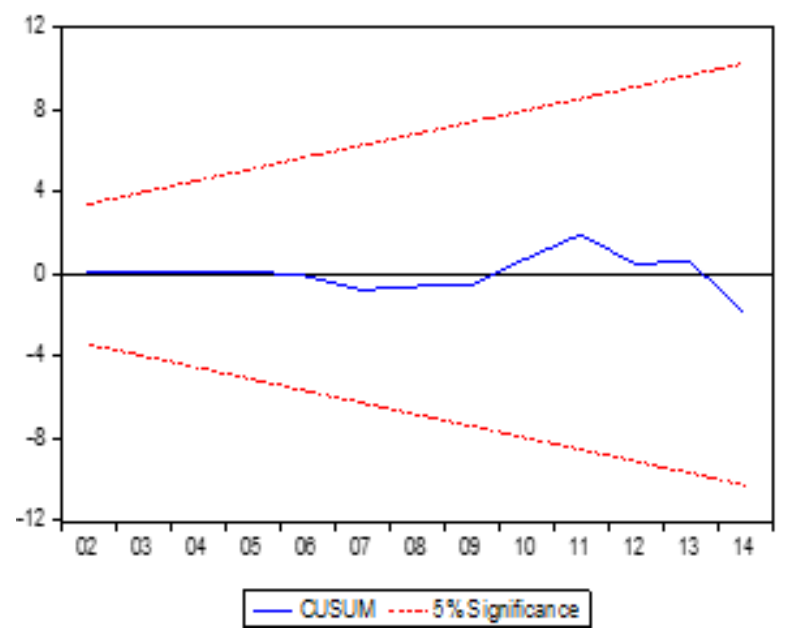

Figure 3. Cusum Stability Test

\begin{tabular}{lll}
\hline T-statistic & Value & $\mathrm{K}$ \\
\hline F-statistics & 7.6474 & 4 \\
Bond Critical Value & & \\
$10 \%$ & 3.03 & 4.06 \\
$5 \%$ & 3.47 & 4.57 \\
$2.5 \%$ & 3.89 & 5.07 \\
$1 \%$ & 4.4 & 5.72 \\
\hline Table 3. Bond Test & &
\end{tabular}

value (4.57) at the $5 \%$ level. This implies that the null hypothesis of no co-integration among the variables is rejected.

The result as in Table 4 revealed that in the long-run when the main variable of interest has not been introduced, other controlled variables labour, domestic capital, and infrastructure are rightly signed based on theoretical expectation and significant at 5 percent level of significance. Although, in the short run before the introduction of FDI, we could see that labour is not significance at 5 percent level of significance. One possible cause is the available skill set within the domestic economy. With the introduction of FDI in the second model, we could easily identify two immediate effects on the model. First, the FDI has positive significant impact on the aggregate economic growth rate and secondly, the labour variables that was struggling in the previous model became statistically significant even at 5 percent level of significance. And lastly, other variables also exhibit expected signs.

In the third model, we interacted labour with FDI to measure the indirect impact of FDI through labour on the aggregate economic growth of Nigeria and as expected FDI still exert positive significant impact on economic growth rate of Nigeria. However, both labour and infrastructure were seen to suffer in the third model, but domestic capital still return as expected and significant whether in the short-run or in the long-run.

In the last model, the preferred model, we included both direct FDI impact and indirect FDI impacts through labour, and it was discovered that as predicted it became the best of all the models either in the short-run or in the long-run. As seen, FDI impacts even increased further on the aggregate growth rate both in the short-run and in the long-run. The model Rsquare indicates that 83 percent variation in the growth rate of income per capita is explained by foreign direct investment.

We further make effort to check the impact of FDI on the sector-by-sector growth rate or performance. The result as presented in Table 5 revealed that FDI has the greatest impact on the petroleum and gas sector followed by manufacturing sector and construction sector. As expected until labour was interacted with FDI, the result revealed that FDI does not have direct impact on the agricultural sector but however have indirect impact on the sector through labour.

Our finding is consistent with previous finding on the impact of FDI on the aggregate performance of the economy. However, our finding clearly revealed that FDI effect on the economy can also be extracted through its impacts on the labour. As noted by (Gachino; 2007; Ikpesu; 2019) capital and labour are two major ways FDI indirectly impact on the economy which our study has validated. This is because FDI increases the managerial and skill set available in the country and increases the capital stock available for investment purposes in a country. Growth theories recognises the importance of capital stock and labour in driving economic growth across countries. It is important to state clearly however, that foreign direct investment thrives because of capital stock and labour.

\section{Conclusion}

From the study, several conclusions can be reached from the study. The study concludes that there have been several studies that investigated the impact of foreign direct investment on economic growth especially as it relates to the Nigeria economy. Bulk of the studies have revealed a positive relationship between economic growth and foreign direct investment (Ikpesu; 2019; Jaiblai and Shenai; 2019; Anochiwa et al.; 2018; Anowor et al.; 2013) while few studies revealed a negative relationship between economic growth and foreign direct investment (Adeleke and Olowe; 2014).

Our study concludes that have significant positive impact on the aggregate economic growth both in the short run and the long run. We discovered also that FDI not only have direct impact on the economy but also impacts the economy indirectly through labour. Lastly, the study concludes that petroleum and gas sector and manufacturing sector have the greatest impact of foreign direct investment in Nigeria while agriculture is the least impacted in the economy. The implication of the study is that policies aimed at attracting more foreign direct investment 
Table 4. ARDL Models Aggregate Effect of FDI

\begin{tabular}{|c|c|c|c|c|}
\hline Variable & Model 1 & Model 2 & Model 3 & Model 4 \\
\hline $\begin{array}{l}\text { Bounds F-Stats } \\
\text { Long Run Model }\end{array}$ & $7.4584^{* * *}$ & $8.4782 * * *$ & $7.6722 * *$ & $6.6732 * * *$ \\
\hline FDI & & $0.314(0.048) * *$ & & $0.437(0.001) * * *$ \\
\hline LABFDI & & & $0.396(0.000) * * *$ & $0.312(0.017) * * *$ \\
\hline Labour & $0.463(0.0520) * *$ & $0.2574(0.000) * * *$ & $0.278(0.063)^{*}$ & $0.222(0.000) * * *$ \\
\hline DCapital & $0.273(0.042)^{* *}$ & $0.106(0.014) * *$ & $0.165(0.015) * * *$ & $0.562(0.020) * *$ \\
\hline Infrastructure & $0.450(0.026) * *$ & $0.544(0.044) * *$ & $0.107(0.070) *$ & $0.354(0.025) * *$ \\
\hline $\mathrm{C}$ & $0.626(0.007) * * *$ & $-0.649(0.369)$ & $-22.328(0.085) * * *$ & $12.517(0.861)$ \\
\hline$R^{2}$ & 0.7842 & 0.5747 & 0.8453 & 0.7893 \\
\hline $\mathrm{F}^{*}(\mathrm{p}$-value $)$ & $0.0000 * * *$ & $0.0000 * * *$ & $0.0000 * * *$ & $0.0000 * * *$ \\
\hline Breusch-g & 0.4647 & 0.6757 & 0.3564 & 0.4647 \\
\hline Short Run & Model & & & \\
\hline FDI & & $0.816(0.000) * * *$ & & $0.885(0.0301) * *$ \\
\hline LABFDI & & & $0.049(0.048) * *$ & $-0.563(0.013) * * *$ \\
\hline Labour & $0.742(0.090) *$ & $0.215(0.005)^{* * *}$ & $0.240(0.651)^{* *}$ & $0.298(0.000) * * *$ \\
\hline DCapital & $0.456(0.043)^{* *}$ & $7.314(0.038) * * *$ & $0.784(0.002) * * *$ & $0.673(0.001) * * *$ \\
\hline Infrastructure & $0.903(0.024) * *$ & $-0.938(0.000) * * *$ & $-0.638(0.000) * * *$ & $0.782(0.000) * * *$ \\
\hline $\mathrm{C}$ & $0.463(0.010) * * *$ & $-0.649(0.369)$ & $-22.328(0.025) * * *$ & $3.4672(0.861)$ \\
\hline$R^{2}$ & 0.7323 & 0.6924 & 0.7844 & 0.8373 \\
\hline $\mathrm{F}^{*}(\mathrm{p}-\mathrm{value})$ & $0.0000 * * *$ & $0.0000 * * *$ & $0.0000 * * *$ & $0.0000 * * *$ \\
\hline Breusch-g & 0.3674 & 0.832 & 0.2452 & 0.1783 \\
\hline
\end{tabular}

Significance is indicated as follows: $* * *, * *$ and $*$ for $1 \%, 5 \%$ and $10 \%$ respectively, p-value in parenthesis

\begin{tabular}{llll}
\hline Variable & FDI & FDILAB & FDI*S \\
\hline Agriculture sector & $0.034(0.193)$ & $0.214(0.038)^{* *}$ & $0843(0.023)^{* *}$ \\
Petroleum/Gas sector & $0.383(0.000)^{* * *}$ & $0.645(0.064)^{*}$ & $0.563(0.012)^{* * *}$ \\
Manufacturing sector & $0.244(0.043)^{* *}$ & $0.453(0.026)^{* *}$ & $0.257(0.023)^{* *}$ \\
Construction sector & $0.297(0.022)^{* *}$ & $0.557(0.002)^{* * *}$ & $0.245(0.035)^{* *}$ \\
Services sector & $0.209(0.051)^{* *}$ & $0.384(0.024)^{* *}$ & $0.107(0.270)$ \\
C & $0.454(0.003)^{* * *}$ & $2.929(0.086)^{*}$ & $22.328(0.125)$ \\
$R^{2}$ & 0.5732 & 0.8932 & 0.8932 \\
F $^{*}(\mathrm{p}$-value) & $0.0000^{* * *}$ & $0.0000^{* * *}$ & $0.0000^{* * *}$ \\
Breusch-g & 0.344 & 0.236 & 0.572 \\
\hline
\end{tabular}

Table 5. Sectoral Effect of FDI

Source: Authors

like increasing the interest rate to attract more foreign direct investment is also aimed at growing the economy.

\section{Competing Interests}

Authors declare no competing interest.

\section{References}

Acaravci, A. and Ozturk, I. (2012). Foreign direct investment, export and economic growth: Empirical evidence from new eu countries, Romanian Journal of Economic Forecasting 2(1): 110.

URL: http://www.ipe.ro/rjef/rjef2-12/rjef2-2012p52-67.pdf

Adamu, J., Idi, A. and Hajara, B. (2015). Fdi and economic growth nexus: Empirical evidence from nigeria (1970-2012), Journal of Economics and Sustainable Development 6(6): 87-89.

Adeleke, K. M. and Olowe, S. O. (2014). Impact of foreign direct investment on nigeria economic growth, International Journal of Academic Research in Business and Social Sciences 4(8): 234-242.

Akinlo, E. A. (2004). Foreign direct investment and growth in nigeria: An empirical investigation, Journal of Policy Modeling 26(1): 627-639.

Anochiwa, L., Michael, E., Agbanike, T., Nkechi, U., Chukwu,
B. and Ololo, K. (2018). Foreign direct investment and economic growth: Literature from 1980 to 2018, International Journal of Economics and Financial Issues 8(5): 309-318.

Anowor, O. F., Ukweni, N. O., Ibiam, F. O. and Ezekwem, O. S. (2013). Foreign direct investment and manufacturing sector growth, International Journal of Advanced Scientific and Technical 2(3): 15-23.

Banco, S. (2003). Definitions of foreign direct investment (fdi), A methodological note 1(1).

URL: https://www.bis.org/publ/cgfs22bde3.pdf

Denisia, V. (2010). Foreign direct investment theories: An overview of the main fdi theories, Academy of Economic Studies, Buchares 2(2): 1-5.

Dunning, J. H. (1979). Explaining changing patterns of international production: in defence of the eclectic theory, Oxford Bulletin of Economics and Statistics 4(1): 269-295.

URL: doi/10.1111/j.1468-0084.1979.mp41004003

Faroh, A. and Hongliang, S. (2015). Impact of interest rates on foreign direct investment: Case study sierra leone economy, International Journal of Business Management and Economic Research 6(1): 124-132.

Gachino, G. (2007). Foreign direct investment and firm productivity: Evidence from kenyan manufacturing, UNU-MERIT Working Paper Series UNU-20o6 14: 1-13.

Hymer, S. H. (1976). The international operations of national firms: a study of direct foreign investment, Boston:MIT Press. 
Ikpesu, F. (2019). Growth effects of capital inflows and investment in nigeria, International Journal of Management, Economics and Social Sciences (IJMESS) 8(1): 5-19.

Jaiblai, P. and Shenai, V. (2019). The determinants of fdi in sub-saharan economies: A study of data from 1990-201, International Journal Financial Studies 7(43).

URL: doi:10.3390/ijfs7030043

Jones, C. and Yama, T. (2016). The determinants of tax haven fdi, Journal of World Business 51(1): 237-250.

Joseph, E. T., Nwolisa, C., Obikaonu, P. and Alase, G. (2021). Monetary policy effectiveness and financial inclusion in nigeria: Fintech, 'the disrupter' or 'enabler', International Journal of Applied Economics, Finance and Accounting 9: 19-27.

Mundell, R. A. (1957). International trade and factor mobility, American Economic Review 3(47): 321-335.

Nayyar, R. (2014). Traditional and modern theories of fdi, International Journal of Business and Management Invention 3(6): $23-26$.

Obida, G. W. and Abu, N. (2010). Determinants of foreign direct investment in nigeria: An empirical analysis, Global journal of Human Social Science 26(10): 3-7.

Okoli, T. T. and Agu, O. C. (2015). Foreign direct investment flow and manufacturing sector performance in nigeria, International Journal of Economic, Commerce and Management 3(7): 413-428.
Osuji, E. (2015a). Fdi and economic growth linkages in malaysia, Mediterranean Journal of Social Sciences 6(4): 652657.

Osuji, E. (2015b). Foreign direct investment and economic growth in nigeria: Evidence from bounds testing and ardl models, Journal of Economics and Sustainable Development 6(3): 205-211.

Pesaran, H. and Shin, Y. (1999). Autoregressive distributed lag modelling approach to cointegration analysis, London: Cambridge University Press.

Peters, I., Yaaba, B., Adetoba, O., Aduni, T. and Tonuchi, J. (2020). How effective is monetary policy in the presence of high informality in nigeria, Journal of Accounting, Business and Finance Research 10: 84-93.

Romer, D. (2012). Advanced Macroeconomics (4th edition), New York: McGraw-Hill.

Tonuchi, J. and Onyebuchi, N. (2019). Economic diversification in nigeria: The role of agriculture and manufacturing sector, International Journal of Electrical and Computer Engineering 7: $916-926$

UNCTAD (2018). World investment Report 2018, New York: UNCTAD.

URL: https://unctad.org/en/PublicationsLibrary/wir2018-en.pdf 